\title{
Uji Potensi Cendawan Endofit Beauveria bassiana terhadap Perkecambahan dan Pertumbuhan Bibit Tanaman Cabai Merah (Capsicum annuum L.)
}

\author{
Magdalena Saragih*1, Trizelia $^{2}$, Nurbailis ${ }^{2}$, Yusniwati² \\ ${ }^{1}$ Universitas Medan Area \\ ${ }^{2}$ Universitas Andalas \\ *nurastika0@gmail.com
}

\begin{abstract}
Abstrak. Peranan cendawan endofit dalam bidang pertanian banyak mendapat perhatian karena selain dapat meningkatkan ketahanan tanaman terhadap serangan hama maupun penyakit tanaman, juga mempunyai kemampuan dalam memacu perkecambahan dan pertumbuhan tanaman. Salah satu cendawan endofit yang diuji dalam penelitian ini adalah Beauveria bassiana berasal dari isolat tanaman gandum, tanaman kopi, tanaman kakao dan cendawan Beauveria bassiana dari serangga walang sangit (Leptocorisa acuta). Tujuan penelitian ini adalah untuk mengetahui kemampuan kolonisasi cendawan endofit Beauveria bassiana dari isolat gandum, kakao, kopi dan serangga walang sangit terhadap benih dan bibit cabai, untuk mendapatkan waktu yang terbaik dalam memacu perkecambahan dan pertumbuhan bibit cabai melalui metode perendaman benih dengan suspensi Beauveria bassiana selama 2, 6 dan 10 jam. Hasil penelitian menunjukan bahwa semua isolat Beauveria bassiana mampu mengkolonisasi benih maupun bibit tanaman cabai dan $\mathrm{Bb}$ dari isolat gandum merupakan isolat yang terbaik memacu perkecambahan dan pertumbuhan bibit cabai dengan perendaman benih selama 6 jam..
\end{abstract}

Kata kunci: cendawan endofit, Beauveria bassiana, cabai

\section{PENDAHULUAN}

Tanaman cabai (Capsicum annuum L.) merupakan salah satu jenis tanaman pertanian yang memiliki nilai ekonomi yang cukup potensial dan termasuk dalam salah satu jenis kebutuhan pokok bagi masyarakat Indonesia. Dalam upaya pencapaian produktivitas suatu tanaman yang dibudidayakan adalah adanya ketersediaan benih tanaman yang baik. Benih yang baik selain dilihat dari kualitas kesehatan benih, dapat dilihat juga dari tingkat pertumbuhannya, sehingga kualitas benih dapat dilakukan sejak penyediaan dan perlakuan benih. Untuk mendapatkan benih yang berkualitas dapat dilakukan dengan penambahan berbagai unsur hara, zat pengatur tumbuh, cara kultur teknis ataupun dengan memanfaatkan mikroba fungsional (Sutariati dan Saufan, 2012); Agustiansyah et al. (2013) Cendawan endofit merupakan salah satu jenis mikroba fungsional yang mampu memproduksi metabolit sekunder baik secara langsung atau tidak langsung dapat mempengaruhi pertumbuhan inangnya (Calvo et al., 2002, Agusta, 2009). Mikroba endofit adalah mikroba yang hidup di dalam jaringan tanaman pada periode tertentu dan mampu hidup dengan membentuk koloni dalam jaringan tanaman tanpa membahayakan inangnya (Kambrekar, 2016).

Interaksi yang terjadi antara cendawan endofit dan tanaman tidak menyebabkan gejala penyakit dimungkinkan karena hubungan antara endofit dan tanaman bersifat antagonisme yang seimbang (Schulz \& Boyle, 2005). Interaksi antara mikroba endofit dengan inangnya, endofit akan mendapat keuntungan berupa adanya pasokan nutrisi, terlindungi dari tekanan lingkungan yang kurang menguntungkan yang membantu dalam upaya reproduksi dan kolonisasi. Tanaman inang pada umumnya dapat memperoleh keuntungan berupa adanya penginduksian ketahanan terhadap berbagai tekanan, baik oleh faktor biotik maupun abiotik, juga dapat meningkatkan pertumbuhannya yaitu melalui produksi fitohormon, peningkatan akses terhadap mineral dan nutrisi serta sintesis metabolit antagonis (Jeffrey et al., 2008., Agusta, 2009). Penggunaan mikroba endofit dalam pengendalian beberapa jenis pengganggu tanaman telah mulai banyak diteliti baik organisme pengganggu tanaman telah mulai banyak diteliti, baik organisme pengganggu dari jenis hama,

To cite this article: Saragih, M., Trizelia, Nurbailis, dan Yusniwati. 2019. Uji Potensi Cendawan Endofit Beauveria bassiana Terhadap Perkecambahan dan Pertumbuhan Bibit Tanaman Cabai Merah (Capsicum annuum L.). Unri Conference Series: Agriculture and Food Security 1: 151-159. https://doi.org/10.31258/unricsagr.1a20 
patogen tanaman maupun pengaruhnya terhadap tingkat toleransi tanaman dalam menghadapi kondisi lingkungan yang ekstrim, misalnya kekeringan (Hormazabal et al., 2005; Damayanti, 2013; Singh et al., 2013). Akan tetapi informasi mengenai pemanfaatan cendawan endofit dalam meningkatkan perkecambahan dan pertumbuhan cabai belum banyak diperoleh. Tujuan penelitian ini adalah mengetahui kemampuan kolonisasi cendawan endofit Beauveria bassiana terhadap perkecambahan dan pertumbuhan tanaman cabai melalui perendaman benih dengan waktu perendaman benih yang terbaik dalam memacu perkecambahan dan pertumbuhan bibit cabai guna mendukung pengembangan strategi penyediaan benih sehat yang berwawasan lingkungan.

\section{METODE}

\section{Waktu dan Tempat}

Kegiatan penelitian ini dilakukan di Laboratorium Pengendalian Hayati dan Rumah Kasa Universitas Andalas, sejak bulan juni hingga Agustus 2018. Bahan yang digunakan dalam penelitian ini adalah benih cabai, isolat B.bassiana dari kopi, kakao, gandum dan walang sangit. Benih cabai yang akan diperlakukan untuk pengujian perkecambahan adalah benih cabai lokal dari pertanaman cabai di padang panjang Sumatera Barat.

\section{Persiapan Suspensi}

Pembuatan larutan suspensi Beauveria bassiana adalah dengan cara memanen cendawan B.bassiana yang ditumbuhkan pada media SDAY yang sudah berumur 2 minggu, kemudian dibuat larutan suspensi cendawan Beauveria dengan menambahkan aquadest dan suspensi diencerkan hingga pengenceran 108/ml. Kepadatan konidia cendawan dihitung dengan menggunakan haemocytometer. Benih cabai yang akan digunakan disterilisasi permukaannya dengan alkohol 70\% selama 1-2 menit, kemudian dibilas 3 kali dengan aquades steril. Setelah benih ditiriskan, kemudian benih direndam masing masing dengan perlakuan watu 2 jam, 6 jam dan 10 jam dalam suspensi cendawan endofit yang telah dipersiapkan yakni sebanyak 50 benih dalm 10 ml suspensi untuk setiap perlakuan. Benih diambil, kemudian ditiriskan, sebagai kontrol, benih hanya disterilisasi permukaannya dengan aquadest.

\section{Uji Perkecambahan Benih Cabai di Laboratorium}

Untuk mengetahui kemampuan cendawan endofit B.bassiana memicu perkecambahan benih cabai dilakukan dengan uji Blotter. Benih cabai disterilisasi permukaan menggunakan alkohol $70 \%$ selama 2 menit, kemudian dibilas dengan akuades steril sebanyak 2 x. Setelah itu dilakukan perendaman benih cabai pada masing masing larutan suspensi Beauveria pada pengenceran 108/ml. Benih cabai direndam dengan 3 perlakuan waktu yakni perendaman 2 jam, 6 jam dan 10 jam. Benih cabai yang sudah direndam dipindahkan ke dalam cawan petridish yang telah dialasi dengan kertas saring dengan jumlah masing masing benih cabai sebanyak 25 benih dan diulang sebanyak 8 kali. Rancangan yang digunakan adalah RAL.

\section{Variabel dan Pengamatan}

Variabel yang diamati dalam perlakuan ini adalah terhadap persentase tumbuh benih dilakukan setiap hari sampai hari ke 7. Evaluasi daya kecambah dihitung dengan menggunakan metode Sadjad (1994) dalam Suita dan Syamsuwida (2015).

$$
\mathrm{DB}=\mathrm{KN} / \mathrm{N} \times 100 \%
$$

dimana:

$\mathrm{KN}=$ jumlah benih yang berkecambah normal

$\mathrm{N}$ = Jumlah benih yang ditabur

\section{Uji Pertumbuhan Bibit Tanaman Cabai Dengan Metode Perendaman Benih}

Uji pertumbuhan bibit cabai dilakukan di rumah kasa Fakultas Pertanian Universitas Andalas dimulai bulan Juli hingga bulan Agustus 2018. Bahan yang digunakan dalam penelitian ini adalah benih cabai yang telah direndam dengan masing masing suspensi Beauveria bassiana pada pengenceran 108/ml. Benih cabai disemai pada baki semai yang mempunyai lubang semai 50 lubang dengan media tanaman berupa berupa semai komersil. Tanah yang digunakan adalah tanah steril., dengan campuran pupuk kandang 2:1. Setiap perlakuan diulang 3 kali dan setiap ulangan menggunakan sebanyak 5 benih. Variabel pengamatan terhadap perkecambahan benih, pertumbuhan tinggi tanaman cabai, jumlah daun dan persentase kolonisasi cendawan 
pada daun, akar dan batang bibit cabai. Pengamatan dilakukan pada usia bibit cabai 6 minggu. Rancangan yang digunakan adalah Rancangan Acak Lengkap.

\section{Pengamatan Daya Kecambah Benih}

Pengukuran daya kecambah benih dengan menggunakan rumus:

$$
\mathrm{DB}=\mathrm{KN} / \mathrm{N} \times 100 \%
$$

\section{Perlakuan kolonisasi cendawan endofit}

Uji kolonisasi cendawan endofit pada bibit tanaman cabai dilakukan dengan metode Rodrigues (1994) yang telah dimodifikasi. Bibit cabai yang berumur 6 MSS yang telah diinokulasi cendawan endofit diambil sebanyak 3 tanaman. Reisolasi cendawan endofit dari bagian tanaman seperti akar, batang dan daun disterilisasi permukaan secara bertahap melalui perendaman alkohol $70 \%$ selama 1 menit, $\mathrm{NaOCl} 1 \%$ (akar) dan $\mathrm{NaOCl} 3 \%$ (batang dan daun) selama 2 menit serta alkohol 70\% selama 30 detik. Selanjutnya masing masing bagian tanaman dibilas sebanyak 3 kali dengan aquades steril dan dikeringanginkan kemudian dipotong kecil dan diletakkan pada cawan petri yang telah berisi media Oat. Selanjutnya diinkubasi pada keadaan gelap selama 7-10 hari. Potongan jaringan tanaman diamati setiap hari terhadap miselium yang tumbuh. Miselium kemudian dipindahkan ke media SDY untuk pemurnian, selanjutnya diidentifikasi secara mikroskopis.

\section{Variabel Pengamatan}

Pengamatan yang dilakukan adalah terhadap perhitungan kolonisasi cendawan endofit dilakukan dengan menggunakan rumus mengikuti metode Rodrigues (1994):

$$
\text { Kolonisasi CE }=\mathrm{n} / \mathrm{N} \times 100 \%
$$

dimana:

$\mathrm{CE}=$ Cendawan endofit

$\mathrm{N}=$ jumlah potongan sampel tanaman yang terinfeksi cendawan endofit

$\mathrm{N}=$ jumlah potongan sampel tanaman yang diamati

\section{Analisa Data}

Data uji potensi cendawan endofit diolah secara statistik dan deskriptif, berupa rerata yang ditampilkan dalam tabel dan gambar. Analisis statistik dilakukan menggunakan Analisis Varian (ANOVA), dan perlakuan yang berbeda nyata dilanjutkan dengan uji Duncan Multiple Range Test(DMRT) pada taraf kepercayaan 95\%, menggunakan program SPSS versi 16.0.

\section{HASIL DAN PEMBAHASAN}

\section{Pengaruh cendawan endofit Beauveria bassiana terhadap perkecambahan benih di Laboratorium}

Hasil pengamatan perlakuan uji potensi cendawan endofit $B$. bassiana dengan perlakuan perendaman benih selama 2 jam, 6 jam dan 10 jam menunjukkan bahwa, perendaman benih cabai dengan suspensi $B$. bassiana berpengaruh terhadap perkecambahan benih cabai di laboratorium. Semua isolat B. bassiana yang diuji berpengaruh terhadap perkecambahan benih cabai dengan persentase perkecambahan benih rata-rata diatas $85.00 \%$. Pada perendaman benih selama 2 jam, persentase kecambah yang tertinggi terdapat pada isolat gandum sebesar $93.00 \%$, diikuti oleh isolat walang sangit sebesar $90.00 \%$, isolat kakao $89,50 \%$ dan isolat kopi sebesar $88,00 \%$, sedangkan perendaman pada kontrol, perkecambahan cabai mencapai 75,50\%. Berdasarkan analisa statistik, tidak ada perbedaan yang nyata antara perlakuan kecuali pada kontrol. Pada perlakuan perendaman benih cabai dengan waktu 6 jam menunjukkan adanya peningkatan persentase perkecambahan dibandingkan dengan perlakuan waktu perendaman benih selama 2 jam, dari data statistik terlihat bahwa persentase perkecambahan yang tertinggi terdapat pada isolat gandum sebesar 98,00\% diikuti oleh isolat walangsangit sebesar 95,50 \% dan isolat kakao sebesar 93,00\% dan isolat kopi sebesar 92,50\%. Perlakuan perendaman benih yang tertinngi pada isolat gandum berbeda nyata dengan isolat kopi sedangkan antar isolat walangsangit dan kakao tidak terdapat perbedaan yang nyata kecuali dibandingkan dengan kontrol. Pada perlakuan waktu perendaman benih selama 10 jam menunjukkan tidak ada peningkatan persentase perkecambahan benih yang signifikan meningkat bila dibandingkan dengan waktu perendaman benih 6 jam, hal ini menunjukkan bahwa antara waktu perendaman benih 6 jam dan 10 jam tidak berpengaruh terhadap perkecambahan benih kecuali bila dibandingkan dengan kontrol. Dari analisa statistik tidak terdapat perbedaan yang nyata antara perlakuan isolat terhadap perkecambahan. Berdasarkan perlakuan 
waktu perendaman benih dengan suspensi B.bassiana, isolat gandum merupakan isolat yang paling tinggi pengaruhnya terhadap perkecambahan benih cabai, dengan data ini dapat dianjurkan untuk memicu perkecambahan benih dapat mengaplikasikan nya dengan suspensi B.bassiana isolat gandum. Data pengaruh cendawan endofit terhadap perkecambahan benih cabai dapat dilihat pada Tabel 1 dan Gambar 2. Inokulasi cendawan endofyt pada benih dapat meningkatkan persentase perkecambahan. Menurut Dearnaley dan Brocque (2006), kolonisasi cendawan endofyt memiliki peran penting pada saat perkecambahan. Pada saat benih berkecambah, benih hanya memiliki sedikit kandungan nutrisi essensial. Pada saat benih berkecambah, hifa cendawan endofyt mengkolonisasi jaringan tanaman dan membentuk struktur yang disebut pelotons. Struktur tersebut digunakan cendawan endofyt untuk melakukan pertukaran nutrisi , sedangkan benih mendapatkan suplai gula substansi anorganik (nitrogen dan fosfor) yang berguna bagi pertumbuhan tanaman muda. Beberapa cendawan endofyt memproduksi fitohormon seperti auksin, sitokinin dan etilen (Bacon et al, 2001; Tan and Zou, 2001).

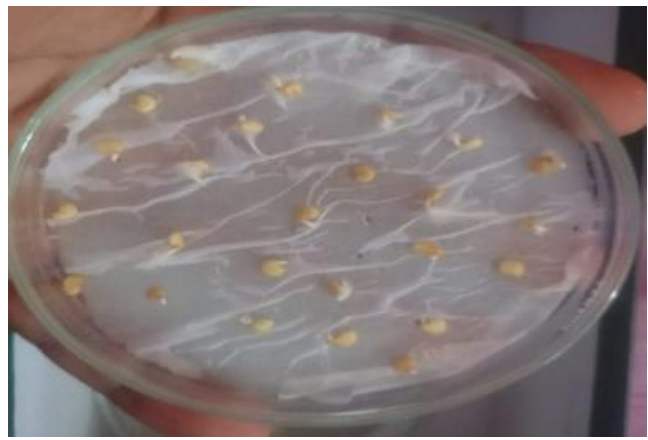

Gambar 1. Uji perendaman benih cabai dengan suspensi cendawan B.bassiana di laboratorium

Tabel 1. Pengaruh waktu perendaman benih cabai dengan suspensi cendawan endofit B.bassiana terhadap perkecambahan benih cabai di laboratorium

\begin{tabular}{lccc}
\hline \multicolumn{1}{c}{ Kode Isolat } & \multicolumn{3}{c}{ Persentase Perkecambahan Benih Cabai } \\
& Perendaman 2 jam & Perendaman 6 jam & Perendaman 10 jam \\
\hline Isolat Kakao & $89,50 \mathrm{a}$ & $93.50 \mathrm{a}$ & $93,50 \mathrm{a}$ \\
Isolat kopi & $88,00 \mathrm{a}$ & $93,50 \mathrm{a}$ & $93,00 \mathrm{a}$ \\
Isolat Gandum & $93,50 \mathrm{a}$ & $98,00 \mathrm{a}$ & $97,50 \mathrm{a}$ \\
Isolat Walangsangit & $90,00 \mathrm{a}$ & & $95,50 \mathrm{a}$ \\
Kontrol & $75,50 \mathrm{~b}$ & $79.00 \mathrm{~b}$ & $81,50 \mathrm{a}$ \\
\hline
\end{tabular}

Potensi ataupun kemampuan cendawan endofit B.bassiana dalam memicu perkecambahan benih cabai dapat terlihat pada perlakuan perendaman benih cabai dengan suspensi cendawan B.bassiana dibandingkan dengan kontrol. Peranan dari cendawan endofit terhadap perkecambahan terlihat dari tingginya persentase perkecambahan di dalam uji blotter dengan menggunakan media pertumbuhan di dalam petridish. Performa dari benih yang tumbuh memperlihatkan benih yang sehat, normal dan tidak cacat, rata rata diatas 85 persen. Inokulasi cendawan endofit pada benih dapat meningkatkan persentase perkecambahan. Cendawan endofit dapat diaplikasikan dalam pertanian pada saat awal pembenihan, Perlakuan ini dapat membantu benih untuk bisa tumbuh dan berkembang. Menurut Kartika (2013), perkecambahan benih yang normal adalah kecambah dengan perkembangan sistem akar, hipokotil, plumula dan kotiledon yang baik tanpa ada kerusakan atau kelainan pada jaringan-jaringan nya. Cendawan endofit dapat memicu pertumbuhan tanaman dengan menghasilkan berbagai substansi hormon yang berbeda terhadap pertumbuhan tanaman. Adanya interaksi endosymbiont dari cendawan endofyt dalam jaringan tanaman dapat menghasilkan hormon auxin yang meningkatkan pertumbuhan vegetatif. Terjadinya mekanisme peningkatan toleransi terhadap kekeringan dalam tanaman disebabkan oleh kemampuan yang tinggi dari jaringan meristem untuk memulihkan tanaman dari kondisi kekeringan. Menurut Anand et al. (2006), potensi cendawan endofit dalam memicu pertumbuhan tanaman dapat melalui mekanisme secara langsung dan tidak langsung. Mekanisme secara langsung salah satu diduga dengan melibatkan produksi senyawa pengatur tumbuh (Dai et al. 2008, Waqas et al. 2012) atau meningkatkan ketersediaan nutrisi yang terbatas untuk peningkatan pertumbuhan tanaman, sedangkan mekanisme secara tidak langsung, adalah melalui penekanan terhadap mikroba pengganggu (Gao et al., 2010). Rodriguez et al. (2009), menguraikan, cendawan endofit yang mampu meningkatkan pertumbuhan tanaman inangnya termasuk ke dalam kelas 2 yakni cendawan non clavicipetales. Fungsi cendawan pada tanaman, dapat meningkatkan pertumbuhan dan adaptasi tanaman (Clay, 1990). 


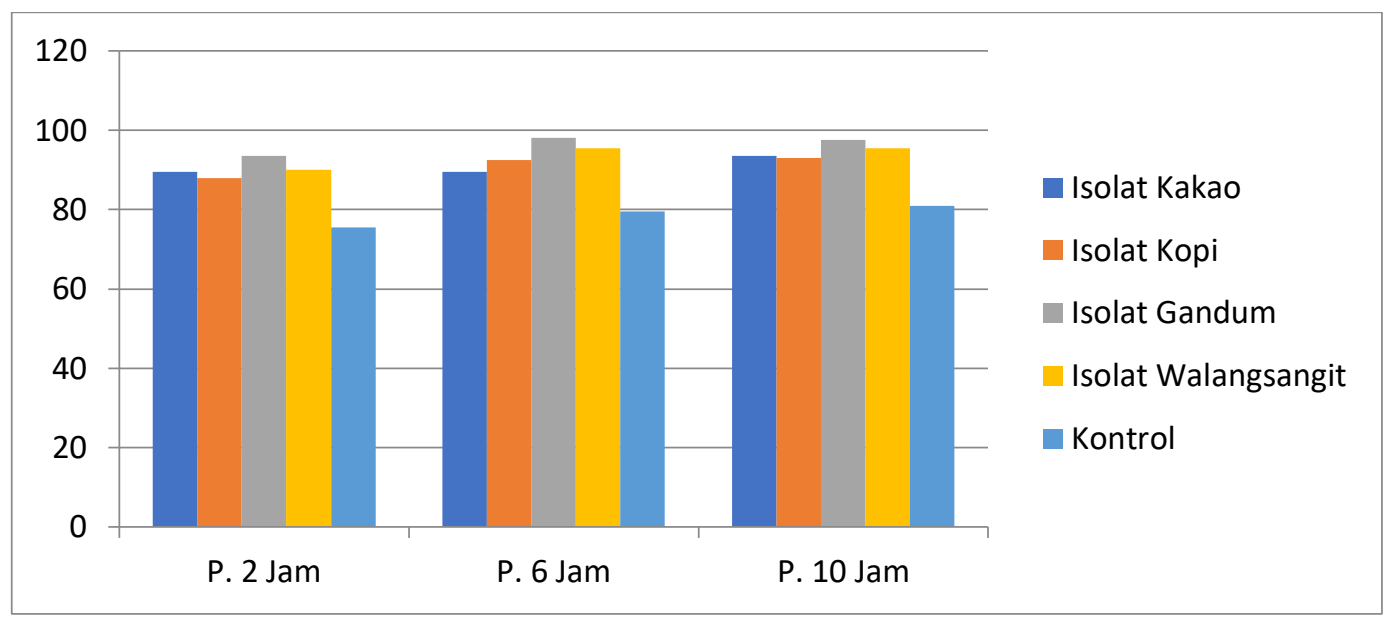

Gambar 2. Persentase perkecambahan benih cabai pada perlakuan beberapa suspensi isolat cendawan B.bassiana

\section{Pengaruh Cendawan Endofit Terhadap Pertumbuhan Bibit Tanaman}

Kemampuan cendawan endofyt dalam memicu pertumbuhan tanaman, secara langsung diduga adanya peranan dari senyawa pengatur tumbuh dalam tanaman. Hormon pengatur tumbuh adalah senyawa organic yang dapat mendorong, menghambat atau secara kualitatif mengubah pertumbuhan dan perkembangan tanaman (Wattimena, 1992). Hormon pemacu pertumbuhan terdiri dari 5 golongan yakni auksin, giberellin, sitokinin, asam absisat dan etilen. Asam indole asetat (IAA). Cendawan endofit Wiliopsis sturnus asal tanaman jagung mampu menghasilkan hormone perangsang pertumbuhan tanaman, yaitu IA dan Indole-3pyrufic acid (IPYA) (Nassar et al., 2005). Berdasarkan hasil pengujian kemampuan cendawan endofyt terhadap pertumbuhan bibit cabai dapat dilihat pada Tabel 2 .

Tabel 2. Pengaruh waktu perendaman benih terhadap pertumbuhan bibit cabai pada pengamatan 7 MST

\begin{tabular}{|c|c|c|c|}
\hline \multirow{2}{*}{ Kode Isolat } & \multicolumn{3}{|c|}{ Rata-rata Tinggi Tanaman Cabai $(\mathrm{Cm})$} \\
\hline & Perendaman 2 jam & Perendaman 6 jam & Perendaman 10 jam \\
\hline Isolat Kakao & $12,4 \mathrm{a}$ & $27,2 \mathrm{~b}$ & $35 \mathrm{a}$ \\
\hline Isolat kopi & $14,6 \mathrm{a}$ & $25,2 b$ & $36,6 a$ \\
\hline Isolat Gandum & $15,4 \mathrm{a}$ & $36,8 \mathrm{a}$ & $38,6 a$ \\
\hline Isolat Walangsangit & $12,5 \mathrm{a}$ & $28,5 b$ & $35,0 \mathrm{a}$ \\
\hline Kontrol & $14,4 \mathrm{a}$ & $26,8 b$ & $33,4 \mathrm{a}$ \\
\hline
\end{tabular}

Aplikasi cendawan endofyt $B$. bassiana memberikan pengaruh yang baik terhadap pertumbuhan bibit cabai. Dari data pada tabel 2 terlihat rata-rata tinggi tanaman menunjukkan peningkatan pada setiap pengamatan, dan pada pengamatan 7 MST, rata-rata tinggi tanaman pada perlakuan perendaman benih cabai baik antara perendaman 6 dan 10 jam menunjukkan perbedaan tinggi tanaman. Dari hasil uji statistik terdapat perbedaan yang nyata antara perlakuan isolat gandum dengan isolat dari kakao, isolat kopi, walang sangit dan kontrol, antara perlakuan isolat kakao, kopi dan walangsangit tidak menunjukkan perbedaan yang nyata. Perbedaan angka tinggi tanaman cabai pada perlakuan dengan isolat gandum pada perendaman 6 jam dan 10 jam tidak menunjukkan perbedaan yang nyata. Dengan demikian, isolat gandum merupakan isolat cendawan endofyt yang terbaik dalam memicu atau meningkatkan pertumbuhan tanaman. Bila dibandingkan dengan data jumlah daun pada Tabel. 3, terlihat bahwa jumlah daun pada perlakuan perendaman 6 jam dan 10 jam menunjukkan peningkatan jumlah daun cabai. Jumlah daun cabai pada perendaman 6 jam diantara perlakuan tidak menunjukkan perbedaan yang nyata kecuali pada kontrol. Pada pengamatan jumlah daun cabai pada perlakuan perendaman cabai 10 jam. 

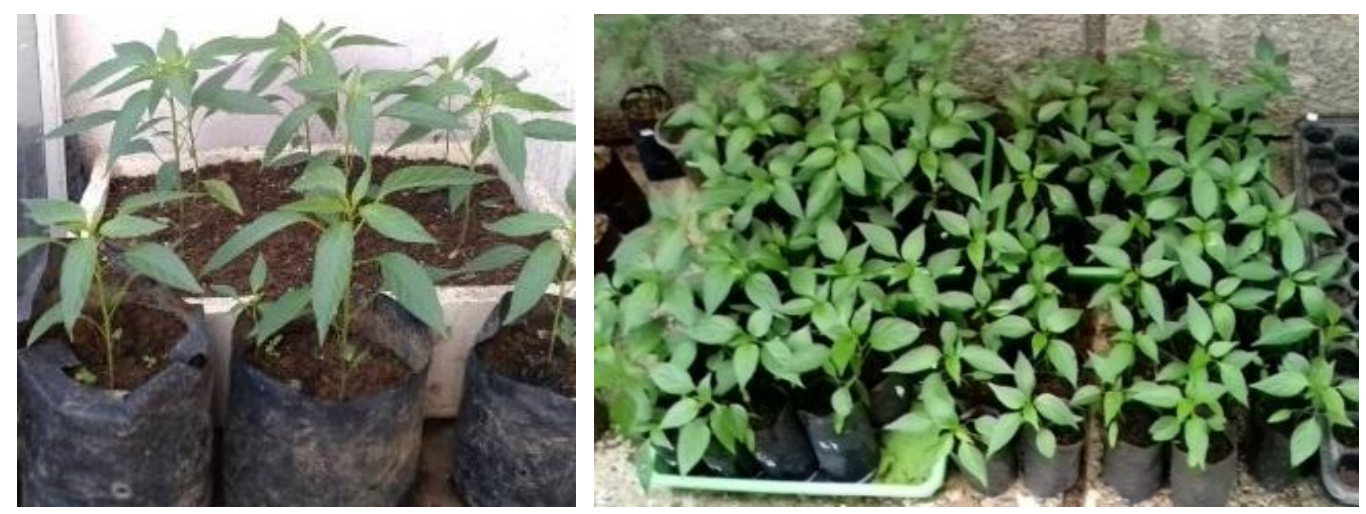

Gambar 3. Pertumbuhan bibit cabai setelah perlakuan perendaman benih cabai dengan suspensi cendawan B.bassiana pada usia 5 MST

Tabel 3. Rata-rata jumlah daun cabai pada perlakuan perendaman benih cabai dengan suspensi B.bassiana

\begin{tabular}{lccc}
\hline \multicolumn{1}{c}{ Kode Isolat } & \multicolumn{3}{c}{ Rata-rata Jumlah Daun Tanaman Cabai } \\
& Perendaman 2 jam & Perendaman 6 jam & Perendaman 10 jam \\
\hline Isolat Kakao & $9 \mathrm{a}$ & $13 \mathrm{ab}$ & $29 \mathrm{~b}$ \\
Isolat kopi & $9 \mathrm{a}$ & $14 \mathrm{ab}$ & $28 \mathrm{~b}$ \\
Isolat Gandum & $10 \mathrm{a}$ & $17 \mathrm{a}$ & $39 \mathrm{a}$ \\
Isolat Walangsangit & $10 \mathrm{a}$ & $14 \mathrm{ab}$ & $35 \mathrm{a}$ \\
Kontrol & $8 \mathrm{a}$ & $10 \mathrm{~b}$ & $25 \mathrm{~b}$ \\
\hline
\end{tabular}

Inokulasi cendawan endofyt terhadap pertumbuhan bibit tanaman cabai melalui perendaman benih dengan suspense B.bassiana berpengaruh nyata terhadap tinggi maupun jumlah daun cabai. Sebagai mikroba endofyt, cendawan endofyt dapat mmemasuki jaringan tanaman melalui biji atau benih secara horizontal (Zabalgogeazcoa, 2008). Endofyt secara natural dapat berada pada biji tanaman, dan pertumbuhan tanaman dapat meningkat seiring peningkatan level mikroba endofyt yang berada pada tanaman. Untuk melihat adanya pengaruh cendawan endofyt terhadap pertumbuhan bibit tanaman melalui perendaman benih cabai dapat dilakukan dengan perlakuan reisolasi cendawan endofyt atau kolonisasi cendawan endofyt Beauveria bassiana dari bagian potongan atau beberapa bagian jaringan tanaman seperti potongan akar, batang maupun daun tanaman cabai. Tanaman cabai yang diuji adalah tanaman cabai berumur 7 MST. Hasil uji kolonisasi cendawan endofyt B.bassiana dapat dilihat pada Tabel.4 dan Gambar 4.

Tabel 4. Persentase kolonisasi cendawan endofyt pada tanaman cabai berumur 7 MST

\begin{tabular}{ccccc}
\hline \multirow{2}{*}{ Isolat } & Parameter & Perhitungan Kolonisasi & J Jam \\
& & Pk \% & Pk \% & Pk \% \\
\hline \multirow{3}{*}{ Kakao } & Akar & 6,7 & 6,7 & 13,3 \\
& Batang & 13,3 & 26,7 & 26,7 \\
& Daun & 6,7 & 26,7 & 33,3 \\
Kopi & Akar & 6,7 & 13,3 & 6,7 \\
& Batang & 6,7 & 33,3 & 13,3 \\
& Daun & 13,3 & 26,7 & 26,7 \\
Gandum & Akar & 13,3 & 26,7 & 26,7 \\
& Batang & 13,3 & 40,0 & 33,3 \\
& Daun & 33,3 & 53,3 & 60,0 \\
& Akar & 6,7 & 13,3 & 26,7 \\
& Batang & 6,7 & 33,3 & 33,3 \\
& Daun & 26,7 & 33,3 & 33,3 \\
& Akar & 0,0 & 0,0 & 0,0 \\
& Batang & 0,0 & 0,0 & 0,0 \\
& Daun & 0,0 & 0,0 & 0,0 \\
\hline
\end{tabular}

Pengamatan data persentase kolonisasi cendawan endofyt B.bassiana pada Tabel 4, menjelaskan bahwa semua perlakuan isolate cendawan endofyt $B$. bassiana dapat mengkolonisasi seluruh bagian tanaman baik yang dibawah permukaan tanah maupun di atas permukaan tanah, baik pada perlakuan perendaman 2 jam, 6 
jam maupun 10 jam. Cendawan endofyt terlihat dapat mengkolonisasi akar, batang maupun daun cabai. Keberadaan cendawan endofyt dibawah tanah yakni pada akar lebih rendah disbanding pada daun maupun pada batang cabai. Kolonisasi yang paling tingi persentase nya adalah pada bagian daun tanaman cabai pada perendaman benih selama 10 jam pada isolate gandum sebesar $60 \%$ dan diikuti isolate walangsangit sebesar $33.3 \%$. Pada batang , persentase kolonisasi mencapai $40 \%$ pada perendaman 6 jam dan pada perendaman 10 jam 33,3\% pada isolate gandum, sedangkan pada isolate walangsangit baik pada batang dan daun tidak ada perbedaan persentase kolonisasi cendawan baik pada perendaman 6 jam maupun 10 jam. Bila dilihat dari data kolonisasi cendawan pada daun tanaman cabai, ada terlihat hubungan antara jumlah daun tanaman dan persentase kolonisasi, dimana jumlah daun yang terbanyak dijumpai pada tanamn cabai isolat gandum demikian juga persentase kolonisasi yang tertinggi juga dijumpai pada daun tanam cabai dengan perlakuan isolate gandum. Menurut Rodriguez et al. (2009), cendawan endofyt dapat bertransmisi secara horizontal dan mampu mengkolonisasi akar, batang dan daun dan dapat meningkatkan biomassa akar dan host shoot. Sementara Jaber dan Vidal (2010), mengemukakan bahwa infeksi beberapa cendawan endofyt dapat meningkatkan pertumbuhan tanaman, toleransi terhadap factor stress tanaman dan tahan terhadap pathogen tanaman dan serangga herbivore. Kandungan chlorofil daun tanaman merupakan parameter untuk mengindikasikan tentang kondisi kebugaran tanaman. Jumlah chlorofyl dalam jaringan daun dapat dipengaruhi oleh factor abiotik yang berbeda seperti ketersediaan nutrisi atau stress oleh factor lingkungan yang disebabkan oleh salinitas, temperature atau supply dari air (Palta, 1990). Faktor biotic juga berpengaruh dan sangat penting dalam kandungan chlorofill pada tanaman. Dalam kasus interaksi tanaman terhadap kapasitas photosyntesa dalam interaksinya dengan cendawan endofyt dapat memproteksi tanaman terhadap pathogen tanaman (Costa Pinto et al, 200). Penyakit Colletotrichum musae dan Fusarium moniliformae dapat mempengaruhi aktifitas fotosintesa tanaman jagung dan pisang, dimana tanaman jagung dapat berkurang kandungan chlorophyll dan aktivitas potosyntesanya terhambat oleh pathogen. Peranan cendawan endofyt $B$. bassiana dapat berinteraksi dengan tanaman jagung dan pisang yang mengaktifkan proses fotosyntesa dapat beraktifitas kembali.

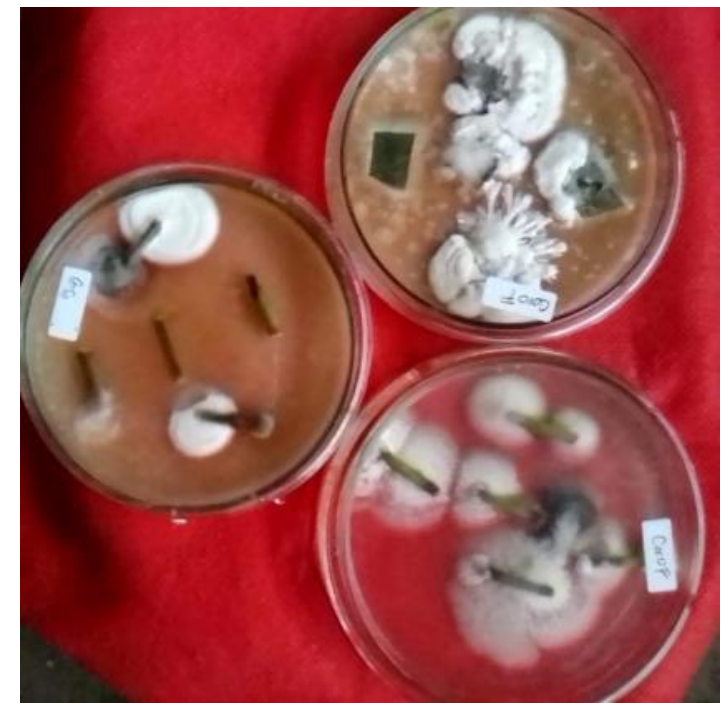

Gambar 4. Kolonisasi cendawan endofyt pada tanaman cabai berumur 7 mst pada perlakuan berbagai waktu perendaman benih cabai dengan suspensi B.bassiana

\section{KESIMPULAN}

Berdasarkan hasil perlakuan perendaman benih cabai dengan suspensi Beauveria bassiana dari isolat Kakao, isolate kopi, isolat gandum dan isolat walang sangit, diperoleh kesimpulan, bahwa cendawan endofyt $B$. bassiana yang diperoleh dari berbagai isolat mampu memicu perkecambahan dan pertumbuhan bibit cabai. Cendawan endofyt yang diperoleh dari berbagai isolat dapat mengkolonisasi tanaman cabai. Isolat yang terbaik meningkatkan perkecambahan dan pertumbuhan tanaman cabai adalah isolat gandum diikuti isolat walangsangit dengan perlakuan lamanya waktu perendaman benih cabai selama 6 jam. Untuk mendapatkan data yang lebih lengkap dari pengujian ini disarankan agar perlakuan berikutnya dilakukan pengujian yang sama dari cendawan B. bassiana terhadap pertumbuhan dan produksi cabai di lapangan. Dari hasil perlakuan 
ini diisarankan agar dilakukan penelitian senyawa metabolit sekunder yang terdapat pada. tanaman cabai yang mampu memicu perkecambahan dan pertumbuhan tanaman.

\section{DAFTAR PUSTAKA}

Agusta, A. 2009. Biologi dan Kimia Jamur Endofyt. Penerbit ITB Bandung. Bandung.

Agustiansyah, I., S. Sudarsono, dan M. Machmud. 2013. Perlakuan Benih dengan Agen Hayati dan Pemupukan P untuk Meningkatkan Pertumbuhan Tanaman, Hasil, dan Mutu Benih Padi, J. Agron. Indones 41(2): 104-98.

Anand, R., I. Paul, and C. Chanway. 2006. Research on Endophytic Bacteria: Recent Advances with Forest Trees. Soil Biology: Mikrobial root Endophytes 9: 106-89.

Bacon, C.W., I.E. Yates, D.M. Hinton, and F. Meredith. 2001. Biological Control of Fusarium Moniliforme in Mayze. Environ Health Perspect 109: 325-332.

Calvo, A.M., R.A. Wilson, J.W. Bok. 2012. Relationship Between Secondary Metabolism and Fungal Development. Microbiology Molecular Biology Rev 66: 447-459.

Clay, K. 1990. Clavicipitaceaous Fungal Endophytes Of Grasses Coevolution and The Changes from Parasitism to Mutualism dalam Pirozinsky KA. Hawksworth, DL., editor. Coevolution of fungi with Plant and Animals. London: Academic Press. London.

Costa Pinto, L., J.L. Azevedo, J.O. Pereire, M.L. Carneiro Vieira, and C.A.A. Labate. 2000. Symtompless Infection of Banana and Maize by Endophytic Fungi Impairs Photosynthetic Efficiency. New Phytol 147: 609-615. https://doi.org/10.1046/j.1469-8137.2000.00722.x

Dai, C.C., Yu By, and X. Li. 2008. Screening of Endophytic Fungi that Promote the Growth of Euphorbia Pekinensis. African Journal of Biotech 7(19): 3510-5.

Damayanti. 2013. Potensi Cendawan Endofyt untuk Menekan Penyakit Daun Keriting Kuning pada Tanaman Cabai (Capsicum аппиит L.), disampaikan dalam seminar hasil penelitian Pascasarjana IPB pada tanggal 17 Januari 20.

Dearnaley, J.D.W., and A.F.L. Brocque. 2006. Endophytic Fungi Associated with Australian Orchids. In Press Australian Mycologist.

Gao, F.K., C.C. Dai, and X.Z. Liu. 2010. Mechanism of Fungal Endophytes in Plant Protection Against Pathogens. African J. of Microbiol Research 4(13): 1351-46.

Hormazabal, E., G.S. Hirschmann, L. Astudillo, J. Rodriguez, and C. Theoduloz. 2005. Metabolites from Microsphaeropsis Olivacea, an Endophytic Fungus of Pilgerodendron Uviferum, Z. Naturforsch 60: 21-11.

Jaber, 1.R., and S. Vidal. 2010. Fungal Endophyte Negative Effects on Herbivory are Enhanced on Intact Plants and Maintained in a Subsequent Generation. Ecol Entomol 35: 25-36. https://doi.org/10.1111/j.13652311.2009.01152.x

Jeffrey, L.S.H., R. Son, and S. Tosiah. 2008. Preliminary Screening of Endophytie Fungi Isolatd from Medical Plants at MARDI Sessang, Sarawak for their Bioactiviy. J. Trop. Agric and Fd.Sc 36(1): 126-1.

Kambrekar, D.N. 2016. New Paradigma in exploration of microbial endophytes in insect pest management. J. Fam Sci. 29(4): 420-435.

Manici, L.M., M. Kelderexr, F. Caputo, and M. Mazzola. 2014. Auxin Mediated Relationships Between Apple Plants and Roof Inhabiting Fungi: Impact on Root Pathogens and Potentialities of Growth-Promoting Populations. Plant Pathol 64(4): 851-43.

Nassar, A.H., K.A. El-tarabily, and K. Sivasithamparam. 2005. Promotion of Plant Growth by An auxin-Producing Isolat of the Yeast Wiliopsis Saturnus Endophytic in Mayze (Zea mays L.) Roots. Biology fertile soil. Voil. 42: 97-106.

Palta, P.J. 1990. Leaf chlorophyll content. Remote Sens. Rev., 207-213. Available online at: http://www.tandfonline.com/doi/pdf/10.1080/027572590095321299 Accessed September 2018.

Rodriguez, R.J., J.F. White, A.E. Arnold, R.S. Redman. 2009. Fungal endhopytes: diversity and fungsional roles. New Phytol. 182: 314-330. https://doi.org/10.1111/j.1469-8137.2009.02773.x

Schulz, B., and C. Boyle. 2005. The Econtinuum. Mycological Research 109: 661-686. 
Singh, UB, N. Sahu, B.P. Singh, H.B. Singh, M.C. Manna, A.S. Rao, and S.R. Prasad. 2013. Can Endophytic Arthrobotrys Oligospora Modulate Accumulation of Defence Related Biomolecules and Induced Systemic Resistance in Tomato (Lycopersicum esculentum Mill.) Against Root Knot Disease Caused by Meloydogyne Incognita, Appli. Soil Ecol 63: 56-45.

Suita dan Syamsuida. 2015. Peningkatan Daya Kecepatan Berkecambah Berkecambah Benih. Malapari (Pongamia pinnata).

Sutariati, G.A.K., and L.O. Saufan. 2012. Perlakuan Benih dengan Rhizobakteri Meningkatkan Mutu Benih dan Hasil Cabai (Capsicum annuum L.), J.Agron. Indones 40(2): 131-25.

Tan, R.X., and W.X. Zou. 2001. Endophytes: a Rich Source of Functional Metabolites. Nat Prod Rep.18: 448-459.

Waqas, M., A.L. Khan, M. Kamran, M. Hamayun, S.M. Kang, Y.H. Kim, and I.J. In-Jung Lee. 2012. Endophytic Fungi Produce Gibberellins and Indoleacetic Acid and Promotes Host-Plant Growth during Stress, Molecules 17: 10773-542012.

Wattimena, G.A.M., Livy, S. Nurhayati. E. Endang, dan Andri. 1992. Bioteknologi Tanaman. Bogor: Pusat antar Universitas Bioteknologi, Institut Pertanian Bogor.

Widajati, E., E. Murniati, E.R. Palupi, T.Kartika, M.R. Suhartanto, and A. Qodir. 2013. Dasar Ilmu dan Tehnologi Benih. Bogor: IPB Press.

Zabalgogeazcoa, I. 2008. Fungal Endophytes and Their Interaction with Plant Pathogens. Spanish Journal of Agricultural Research 6: 138-146. https://doi.org/10.5424/sjar/200806s1-382 